\title{
Effect of Plant Growth Regulators on Propagule Formation in Hemerocallis spp. and Hosta spp.
}

\author{
Mélanie Leclerc, Claude D. Caldwell, and Rajasekaran R. Lada \\ Department of Plant and Animal Sciences, Nova Scotia Agricultural College, \\ Truro, NS, Canada
}

\section{Jeffrey Norrie Acadian Seaplants Limited, 30 Brown Avenue, Dartmouth, NS, Canada}

\begin{abstract}
Field experiments were conducted in 2002 and 2003 to evaluate the effects of selected plant growth regulators on propagule production in Hemerocallis 'Happy Returns' and Hosta 'Gold Standard'. Benzyladenine (BA), chlormequat chloride (Cycocel), ethephon (Ethrel), prohexadione calcium (Apogee), and an experimental preparation of commercial seaweed extract (Acadian Seaplants Limited Liquid Seaweed Concentrate) amended with BA and IBA were tested at two times of application and three rates of application. Results with Hemerocallis showed that the application of the seaweed/PGR mixture at $3000 \mathrm{mg} \cdot \mathrm{L}^{-1}$, Cycocel at $3000 \mathrm{mg} \cdot \mathrm{L}^{-1}$ or BA at $2500 \mathrm{mg} \cdot \mathrm{L}^{-1}$ applied at flowering, increased the number of plants producing two divisions compared to control plants. In Hosta, no increase in divisions under any treatments was observed.
\end{abstract}

In fast-track field production of bare-root perennials, plants are grown for only one season. They are transplanted into the field in the spring, harvested and divided in the autumn of the same year. In this system, the objective is to produce as many reproductive divisions, or propagules, as possible from the plant harvested. Hemerocallis and Hosta are conventionally propagated by crown division but the number of propagules obtained through this technique is relatively low, only a few plants per mother plant (Keever et al., 1995). The crown is the part of a plant at the surface of the ground from which new shoots and roots are produced (UIUC, 1999). To be viable, a crown division must be composed of shoots, crown and roots. The exogenous application of BA to the mother plant of Hosta has been shown to stimulate offset formation resulting in a more rapid multiplication (Keever et al., 1995). BA also induces differentiation of adventitious buds, breaks bud dormancy, releases lateral buds from apical dominance and stimulates elongation of axillary buds (Keever, 1994). Other plant growth regulators are also used in ornamental horticulture: e.g., ethephon increases lateral branching in ornamental pepper (Khademi and KhoshKhui, 1977); prohexadione-calcium reduces stem elongation in pear and apple (Costa et al., 2001; Guak et al., 2001); and chlormequat chloride produces plants with multiple buds per shoot (Gent and McAvoy, 2000). Prohexadione-calcium and chlormequat chloride are inhibitors of gibberellin biosynthesis, while ethephon is an ethylene-releasing compound. It was postulated that these products might also have an effect on increasing the number of divisions in Hemerocallis and Hosta under the fast-track system.

In the past few decades, interest in using

Received for publication 5 Dec. 2005. Accepted for publication 13 Mar. 2006. seaweed extracts in horticultural and agricultural crops has increased considerably (Norrie and Hiltz, 1999). Their beneficial effects are attributed to the presence of natural plant growth substances, especially cytokinins and substances mimicking cytokinin activity. Cytokinins, as well as other plant biostimulants (e.g., betaines), can improve plant resistance and tolerance to environmental stresses, diseases and insects (Norrie and Hiltz, 1999). Seaweed extracts have also been reported to improve growth, seed germination, flower production, fruit set, crop yield and frost hardiness (Abetz and Young, 1983; Lizzi et al., 1998). Lin and Chuen (1995) demonstrated that seaweed extract, in combination with BA and IBA, increased the number of tillers in Zizania latifolia, a perennial monocotyledon. This suggests that there may be potential for using this treatment combination to increase propagule production in bare-root perennials as well.

With little information available on the species under study, the current research attempted to enhance our knowledge on the effects of selected plant growth regulators on propagule production of Hemerocallis spp. and Hosta spp.

\section{Materials and Methods}

Field experiments were conducted at Balamore Farm Ltd, Great Village, Nova Scotia, Canada $\left(45^{\circ}, 25^{\prime} \mathrm{N} ; 63^{\circ}, 34^{\prime} \mathrm{W}\right)$ in 2002 and 2003. Replicated small plot field trials tested the effects of several plant growth regulators on Hemerocallis 'Happy Returns' and Hosta 'Gold Standard'. In 2002 and 2003, the two crops were planted on 22 and 28 May, respectively, using a modified Mechanical Transplanter model Holland 1500. One perennial bed consisted of three rows, $45 \mathrm{~cm}$ apart, with a spacing of 20 $\mathrm{cm}$ between plants within rows. Irrigation was provided every 3 to $4 \mathrm{~d}$, starting at the end of June. Fields were fertilized before planting with
$560 \mathrm{~kg} \cdot \mathrm{ha}^{-1}$ of $12 \mathrm{~N}-10 \mathrm{P}-20 \mathrm{~K}$, at the beginning of June with $392 \mathrm{~kg} \cdot \mathrm{ha}^{-1}$ of $9 \mathrm{~N}-4 \mathrm{P}-7 \mathrm{~K}$ and at the beginning of August with $336 \mathrm{~kg} \cdot \mathrm{ha}^{-1}$ of 9N-4P-7K. Plots measured $1.5 \times 1 \mathrm{~m}$ in 2002; plot size in 2003 was $1 \times 1 \mathrm{~m}$. Each plot contained 15 to 20 plants; 5 plants per plot were randomly selected for measurements.

In 2002, plant growth regulators were applied using a $\mathrm{CO}_{2}$ backpack sprayer with a 2-m boom and 8002 XR Tee-jet nozzle tips. One nozzle was blocked to allow coverage of $1.5 \mathrm{~m}$ of ground surface. The pressure was set at $207 \mathrm{KPa}$. In 2003, the plots being smaller, one 8003 LP Tee-jet nozzle tip was used and the pressure was set at $138 \mathrm{KPa}$. In both cases, the sprayer was calibrated to deliver $300 \mathrm{~L} \cdot \mathrm{ha}^{-1}$ of spray solution.

\section{Plant growth regulators}

Five different formulations of plant growth regulators were used: 1) liquid formulation of BA, N-6-benzyladenine solution (BAP10) (Plant-Wise Biostimulant Co., Ky.); 2) Cycocel Extra, chlormequat chloride at 460 $\mathrm{g} \cdot \mathrm{L}^{-1}$ active ingredient (a.i.) (BASF Canada Inc., Ont., Canada); 3) Ethrel, ethephon at $240 \mathrm{~g} \cdot \mathrm{L}^{-1}$ (a.i.) (Bayer CropScience Inc., AB, Canada); 4) Apogee, prohexadione calcium at $27.5 \mathrm{~g} \cdot \mathrm{L}^{-1}$ (a.i.) (BASF Canada Inc., Ont., Canada); 5) seaweed/PGR mixture: liquid seaweed concentrate (Acadian Seaplants Ltd. liquid seaweed concentrate) (Acadian Seaplants Ltd., NS, Canada), indole-3-butyric acid (4-[3-Indolyl] butanoic acid, potassium salt) (Sigma Aldrich Co.), and N-6-benzyladenine solution (BAP-10) (Plant-Wise Biostimulant Co., Ky.). Commercial names will be used for the remainder of the manuscript.

\section{Statistical design}

Season 1 (2002). A separate three-factor factorial experiment was designed for each crop; the three factors were 1) plant growth regulator type, 2) rate of application, and 3) timing of application. Plant growth regulators used were BA, Cycocel, Ethrel, Apogee, and seaweed extract $+0.10 \%$ IBA $+0.05 \%$ BA. Rates used were $1 \times, 2 \times$, and $3 \times$, which represented different concentration for each product: $\mathrm{BA}=1250,2500$, or $3750 \mathrm{mg} \cdot \mathrm{L}^{-1}$, Cycocel $=1000,2000$, or $3000 \mathrm{mg} \cdot \mathrm{L}^{-1}$, Ethrel $=300,600$ or $900 \mathrm{mg} \cdot \mathrm{L}^{-1}$, Apogee $=75,150$ or $225 \mathrm{mg} \cdot \mathrm{L}^{-1}$, seaweed extract $+0.10 \%$ IBA $+0.05 \%$ BA: 1000,2000 , or $3000 \mathrm{mg} \cdot \mathrm{L}^{-1}$ of seaweed extract. There were two timings of application: 1 July and 1 Aug. 2002.

Each experiment was replicated three times and two untreated control plots were included in each replication. Plants were transplanted into the field on 22 May and harvested on 22 Aug. 2002, due to the need for an early commercial harvest that year (this was an earlier date than planned).

Season 2 (2003). The three plant growth regulators which presented the best results from the previous field season were used for the second season, i.e., BA, Cycocel, and the seaweed/PGR mixture. The two crops were transplanted into the field on 28 May and harvested on 3 Oct. 2003. Factorial design experiments were performed with the same 
factors as for season 1 with the exception that three PGRs instead of five were applied, four rates were tested: 0 (control), $1 \times, 2 \times$, and $3 \times$, and the two timings of application were 9 July and 12 Aug. 2003. Each experiment was replicated three times.

\section{Stages of plant development and data collection}

Season 1 (2002). The first PGR application (1 July) corresponded to the preflowering stage for the two species. Plant height ranged from 10 to $20 \mathrm{~cm}$ for Hemerocallis and growth index ranged from 5 to $15 \mathrm{~cm}$ for Hosta. At the time of the second application (1 Aug.), Hemerocallis plants were flowering and height ranged from 30 to $40 \mathrm{~cm}$. For Hosta, 25\% of plants were also flowering but most remained at a preflowering stage, with a growth index ranging from 10 to $20 \mathrm{~cm}$. At harvest (22 Aug.), Hemerocallis was at the flowering stage and Hosta was at the preflowering stage.

Plant height (measured from the ground to the tallest extended leaf) for Hemerocallis and a growth index $[\mathrm{GI}=($ height + width at widest point + width $90^{\circ}$ to first width)/3] (Keever, 1994) for Hosta were measured on 10 July and 14 Aug.. On 22 Aug., five randomly selected plants were harvested from each plot using a garden fork and the number of divisions per plant was recorded.

Season 2 (2003). Stages of development for both species, at first and second PGR application were the same as in season 1 . The first and second PGR applications were performed on 9 July and 12 Aug. 2003, respectively. At harvest (3 Oct.), both species were at the end of the flowering process.

There were few statistically significant differences in variables measured during the early part of the 2002 season; therefore, variables were measured only at harvest in 2003. Plant height for Hemerocallis and a growth index for Hosta were measured. The number of shoots or fans and the number of divisions per plant were recorded, in addition to shoot and root fresh weights.

\section{Statistical analysis}

For each experiment, data were compiled and analyzed using the statistical software package SAS (SAS Institute Inc., 1999). An analysis of variance at levels $\alpha=0.05$ and $\alpha$ $=0.10$ was conducted on all data sets using the PROC GLM procedure. When means showed significant differences at these levels, a least square means (lsmeans) comparison test was performed. For some data sets, a group comparison using Minitab two-sample $t$ test (Minitab Inc., 2000) was performed to specifically compare untreated plants with plants receiving specific treatments.

\section{Results and Discussion}

\section{Hemerocallis}

The summary of ANOVA for the effect of PGR type, PGR rate and timing of application on the variables measured during the experiments is presented in Table 1.
In 2002, the application of Cycocel at 3000 $\mathrm{mg} \cdot \mathrm{L}^{-1}$ was the only treatment that produced a significantly $(\alpha=0.10)$ higher number of divisions compared to the controls. In the controls, $83 \%$ of plants produced one division per plant and $17 \%$ produced two divisions per plant, while a third of the plants that received Cycocel at $3000 \mathrm{mg} \cdot \mathrm{L}^{-1}$ produced one division and the remaining $66 \%$ produced two divisions per plants (data not shown). This represented a significant increase in economic yield compared to the controls.

In 2003, root fresh weight and the number of divisions per plant were higher for plants treated with the seaweed/PGR mixture and Cycocel at $3000 \mathrm{mg} \cdot \mathrm{L}^{-1}$, both applied at the flowering stage (timing 2), compared to control plants (Table 2). The application of BA at $2500 \mathrm{mg} \cdot \mathrm{L}^{-1}$ also produced more divisions per plant than the controls. The application of the seaweed/PGR mixture at $3000 \mathrm{mg} \cdot \mathrm{L}^{-1}$ produced the highest number of fans per plant (Table 2). For the control plants, $72 \%$ produced two divisions per plant while this proportion increased to $100 \%$ following the application of the seaweed/PGR mixture and Cycocel at $3000 \mathrm{mg} \cdot \mathrm{L}^{-1}$ at flowering (timing 2), and after the application of BA at $2500 \mathrm{mg} \cdot \mathrm{L}^{-1}$ also at this time (Table 3).

Due to the complexity of its composition, the specific mode of action of the seaweed/ PGR mixture is not clear. The cytokinin-like substances (Sanderson and Jameson, 1986), by their action in releasing apical dominance, might be acting on the redistribution of resources toward crown development, producing a higher number of divisions. The presence of other plant biostimulants such as betaines (Whapham et al., 1993), or the presence of macro and micronutrients (Zodape, 2001) may improve the overall growth of the plant allowing for the production of more divisions.
Reallocation of resources may also be observed after the application of Cycocel. By its action as a gibberellin synthesis inhibitor, Cycocel has been shown to reduce shoot growth in many species; consequently, more carbohydrates may preferentially be translocated to crown or root development (Green et al., 1986).

The increase in divisions after BA treatment is consistent with previous studies where BA was shown to induce offset formation in Hosta (Keever, 1994).

\section{Hosta}

In 2002, there was no significant difference due to PGR treatments on the number of divisions per plant of Hosta. In 2003, however, there was a significant interactive effect of PGR type and timing of application for plant height $(P=0.0001)$, growth index $(P=0.049)$, and the number of vegetative buds per plant $(P$ $=0.029$ ) (Table 4$)$. There was no significant effect on shoot and root fresh weight, on the number of shoots per plant or on the number of divisions per plant (data not shown).

These results are inconsistent with previous studies that have evaluated the effect of the exogenous application of BAon Hosta and have resulted in increased offset formation (Keever, 1994). In Keever's experiments, single eye divisions (no offset) were more likely to develop new offsets following the application of BA than were the multiple offset plants. In the current study, since the plants originated from a commercial operation, it is possible that multiple offset plants were initially transplanted in the field and this could have contributed to the lack of response observed. In addition, Keever's (2004) experiments were performed under more controlled conditions offering less impact of environment factors on final results; plants were grown in containers with artificial

Table 1. Summary of ANOVA for the effect of PGR type, PGR rate and timing of application on the number of divisions per plant in 2002 (harvested 22 Sept. 2002); height (cm), shoot and root fresh weight (g), the number of fans, and number of divisions per plant of Hemerocallis 'Happy Returns' in 2003 (harvested 3 Oct. 2003).

\begin{tabular}{|c|c|c|c|c|c|c|c|}
\hline \multirow[b]{2}{*}{$\begin{array}{l}\text { Source } \\
\text { of } \\
\text { variation }\end{array}$} & \multirow[b]{2}{*}{ df } & \multicolumn{6}{|c|}{$P$ values for variables shown } \\
\hline & & $\begin{array}{c}\text { Divisions/ } \\
\text { plant } \\
2002\end{array}$ & $\begin{array}{c}\mathrm{Ht} \\
(\mathrm{cm}) \\
2003\end{array}$ & $\begin{array}{c}\text { Shoot fres } \\
\text { wt (g) } \\
2003\end{array}$ & $\begin{array}{l}\text { Root fresh } \\
\text { wt (g) } \\
2003\end{array}$ & $\begin{array}{l}\text { Fans/ } \\
\text { plant } \\
2003\end{array}$ & $\begin{array}{c}\text { Divisions/ } \\
\text { plant } \\
2003\end{array}$ \\
\hline Replication & 2 & 0.373 & 0.297 & 0.607 & 0.002 & 0.166 & 0.052 \\
\hline PGR & 4 & 0.003 & 0.575 & 0.527 & 0.307 & 0.474 & 0.464 \\
\hline Rate & 2 & 0.561 & 0.382 & 0.313 & 0.029 & 0.452 & 0.044 \\
\hline Timing & 1 & 0.528 & 0.999 & 0.970 & 0.825 & 0.335 & 0.651 \\
\hline $\mathrm{PGR} \times$ rate & 8 & 0.039 & 0.877 & 0.337 & 0.022 & 0.125 & 0.181 \\
\hline PGR $\times$ timing & 4 & 0.162 & 0.622 & 0.637 & 0.109 & 0.685 & 0.914 \\
\hline Rate $\times$ timing & 2 & 0.585 & 0.740 & 0.463 & 0.002 & 0.047 & 0.020 \\
\hline PGR $\times$ rate $\times$ timing & 8 & 0.667 & 0.228 & 0.429 & 0.098 & 0.375 & 0.443 \\
\hline Grand mean & & 1.2 & 42.2 & 40.5 & 112.5 & 4.4 & 2.6 \\
\hline
\end{tabular}

Table 2 Effect of plant growth regulator treatments applied at flowering stage (timing 2) on root fresh weight $(\mathrm{g})$, the number of fans per plant, and the number of divisions per plant recorded at harvest (3 Oct. 2003) for Hemerocallis 'Happy Returns'.

\begin{tabular}{|c|c|c|c|}
\hline $\begin{array}{l}\text { PGR } \\
\text { treatments }\end{array}$ & $\begin{array}{c}\text { Root fresh } \\
\text { wt (g) }\end{array}$ & $\begin{array}{l}\text { Fans/ } \\
\text { plant }\end{array}$ & $\begin{array}{c}\text { Divisions/ } \\
\text { plant }\end{array}$ \\
\hline Control & $103.7 \mathrm{~b}^{\mathrm{z}}$ & $4.1 \mathrm{~b}^{\mathrm{y}}$ & $2.4 b^{z}$ \\
\hline Sw/PGR mix, $3000 \mathrm{mg} \cdot \mathrm{L}^{-1}$ & $141.1 \mathrm{a}$ & $6.7 \mathrm{a}$ & $3.2 \mathrm{a}$ \\
\hline Cycocel, $3000 \mathrm{mg} \cdot \mathrm{L}^{-1}$ & $129.8 \mathrm{a}$ & $4.3 \mathrm{~b}$ & $3.0 \mathrm{a}$ \\
\hline $\mathrm{BA}, 2500 \mathrm{mg} \cdot \mathrm{L}^{-1}$ & $99.3 \mathrm{~b}$ & $4.4 \mathrm{~b}$ & $3.0 \mathrm{a}$ \\
\hline
\end{tabular}

${ }^{\mathrm{z}}$ Means within columns followed by the same letters are not significantly different at $\alpha=0.05$.

${ }^{y}$ Means within columns followed by the same letters are not significantly different at $\alpha=0.10$. 
Table 3 Percentage of plants of Hemerocallis 'Happy Returns' producing one or two divisions per plant under different PGR treatments in 2003.

\begin{tabular}{lrcr}
\hline $\begin{array}{l}\text { PGR } \\
\text { treatments }\end{array}$ & $\mathrm{n}$ & $\begin{array}{c}\text { 1 Division/ } \\
\text { plant (\%) }\end{array}$ & $\begin{array}{c}\text { 2 Divisions/ } \\
\text { plant }(\%)\end{array}$ \\
\hline Controls & 18 & 28 & 72 \\
Sw/PGR mix, 3000 $\mathrm{mg} \cdot \mathrm{L}^{-1}$, timing 2 & 3 & 0 & 100 \\
BA, 2500 mg $\cdot \mathrm{L}^{-1}$, timing 2 & 3 & 0 & 100 \\
Cycocel, 3000 $\mathrm{mg} \cdot \mathrm{L}^{-1}$ timing 2 & 3 & 0 & 100 \\
\hline
\end{tabular}

${ }^{2}$ Timing $1=9$ July; Timing $2=12$ Aug. 2003.

Table 4 Effect of plant growth regulators on plant height $(\mathrm{cm})$, growth index $(\mathrm{cm})$, and the number of vegetative buds per plant for Hosta 'Gold Standard' recorded at harvest (3 Oct. 2003).

\begin{tabular}{|c|c|c|c|c|c|c|}
\hline \multirow[b]{2}{*}{ PGRs } & \multicolumn{2}{|c|}{$\mathrm{Ht}(\mathrm{cm})$} & \multicolumn{2}{|c|}{ Growth index $(\mathrm{cm})$} & \multicolumn{2}{|c|}{ Buds/plant } \\
\hline & Timing $1^{z}$ & Timing 2 & Timing 1 & Timing 2 & Timing 1 & Timing 2 \\
\hline$\overline{\mathrm{Sw} / \mathrm{PGR} \text { mix }}$ & $14.4 \mathrm{a}^{\mathrm{y}}$ & $12.4 \mathrm{c}$ & $24.1 \mathrm{a}$ & $22.2 \mathrm{~b}$ & $2.4 \mathrm{~b}$ & $3.5 \mathrm{a}$ \\
\hline BA & $13.3 \mathrm{~b}$ & $13.6 \mathrm{~b}$ & $23.1 \mathrm{ab}$ & $22.9 \mathrm{ab}$ & $3.3 \mathrm{ab}$ & $3.2 \mathrm{ab}$ \\
\hline Cycocel & $12.8 \mathrm{bc}$ & $13.7 \mathrm{ab}$ & $22.1 \mathrm{~b}$ & $22.9 \mathrm{ab}$ & $3.3 \mathrm{a}$ & $2.6 \mathrm{ab}$ \\
\hline
\end{tabular}

${ }^{\mathrm{z}}$ Timing 1 = 9 July; Timing $2=12$ Aug. 2003.

${ }^{y}$ Means within 2 columns followed by the same letter are not significantly different at $\alpha=0.05 .(n=12)$.

substrate and they were placed in a greenhouse with ventilation and heat set points.

In 2002, due the need for an early commercial harvest, plants of Hemerocallis were still in the flowering process when harvested. As suggested by Zhou et al. (1995), floral buds are very competitive for photosynthates and it is at a later nutrient-storage stage that the assimilates are transported to the crown and root system. This may also explain the lack of response observed in 2002. Plants may need the extra time to show increase in divisions.

Results for Hemerocallis showed that application of the seaweed/PGR mixture, Cycocel, or BAincreased the number of plants producing two divisions compared to control plants. These results have economic implications for bareroot production, which need to be verified on a larger field scale. In a commercial field, plant density is about 150000 plants/ha. In 2003-04, Hemerocallis 'Happy Returns' divisions sold for $\$ 1.60$ each (Balamore Farm Ltd, catalogue 2003-04). If the proportion of plants producing two divisions can be increased from $70 \%$ to $100 \%$, as seen after the application of the seaweed/PGR mixture, Cycocel or BA, this can potentially generate $\$ 480,000 / \mathrm{ha}$ : an increase of $\$ 72,000 /$ ha as compared to a system without plant growth regulators application. The cost to apply plant growth regulators is about $\$ 100 / \mathrm{ha}$, low compared to the possible financial returns due to these treatments.

No conclusive results were observed with Hosta in the course of this study. To show differences in growth and development, it may be necessary to start experiments with Hosta using uniform single offset divisions. This appears to be more important in Hosta than Hemerocallis. Therefore, further investigation with Hosta is needed.

\section{Literature Cited}

Abetz, P. and C.L. Young. 1983. The effect of seaweed extract sprays derived fromAscophyllum nodosum on lettuce and cauliflower crops. Bot. Marina. XXVI :487-492.

Balamore Farm Limited. 2003. Perennial plant catalogue. Balamore Farm Limited, Great Village, Nova Scotia, Can. Fall 2003/Spring 2004.

Costa, G., C. Andreotti, F. Bucchi, E. Sabatini, C. Bazzi, and S. Malaguti. 2001. Prohexadione-Ca $\left(\right.$ Apogee $\left.{ }^{\circledR}\right)$ : Growth regulation and reduced fire blight incidence in pear. HortScience 36(5):931-933.

Gent, M.P.N. and R.J. McAvoy. 2000. Plant growth retardants in ornamental horticulture: A critical appraisal. chapter 4. Plant growth regulators in agriculture and horticulture: Their role and commercial uses. Food Products Press, New York.

Green, C.F., L.V. Vaidyanathan, and J.D. Ivins. 1986. Growth of sugar-beet crops including the influence of synthetic plant growth regulators. J. Agr. Sci. 107(2):285-297.

Guak, S., D. Neilsen, and N.E. Looney. 2001. Growth, allocation of $\mathrm{N}$ and carbohydrates, and stomatal conductance of greenhouse grown apple treated with prohexadione-Ca and gibberellins. J. Hor. Sci. Biotechnol. 76(6):746-752.

Keever, G.J. 1994. BA-induced offset formation in hosta. J. Environ. Hort. 12(1):36-39.

Keever, G.J., D.J. Eakes, and C.H. Gilliam. 1995. Offset stage of development affects hosta propagation by stem cuttings. J. Environ. Hort. 13(1):4-5.

Khademi, M. and M. Khosh-Khui. 1977. Effect of growth regulators on branching,flowering, and fruit development of ornamental pepper (Capsicum annuum L.). J. Amer. Soc. Hort. Sci. $102(6): 796-798$.

Lin, T.C. and S.H. Chuen. 1995. Improvement of cultivation techniques of water bamboo (Zizania latifolia). Bul. Taichung District Agr. Improvement Sta. 47:1-9.

Lizzi Y., C. Coulomb, C. Polian, P.J. Coulomb, and P.O.Coulomb. 1998. Seaweed and mildew: What does the future hold? Phytoma 508:29-30.

Minitab Inc. 2000. Minitab statistical software. Minitab release 13.31.

Norrie, J. and D.A. Hiltz. 1999. Seaweed extract research and applications in agriculture. Agro Food Ind. Hi-Technol. 10(2):15-18.

SAS Institute Inc. 1999. Proprietary software version 8. Cary, N.C.

Sanderson, K.J. and P.E. Jameson. 1986. The cytokinins in a liquid seaweed extract: Could they be the active ingredients? Acta Hort. 179:113-116.

University of Illinois at Urbana-Champaign(UIUC). 1999. Glossary, Introduction to Horticulture. 16 Feb. 2006. http://classes.aces.uiuc.edu/ NRES103/glossary.htm.

Whapham, C.A., G. Blunden, T. Jenkins, and S.D. Hankins. 1993. Significance of betaines in the increased chlorophyll content of plants treated with seaweed extract. J.Appl. Phycol. 5:231-234

Zodape, S.T. 2001. Seaweed as a biofertilizer. J. Sci. Ind. Res. 60 (5):378-382.

Zhou, Y.R. and W.P. Zeng. 1995. Studies on transportation, storage and distribution of carbon assimilates in day-lily (Hemerocallis citrina Baroni). J. S.W. Agr. Univ. 17 (1) 3-7. 